\title{
Between the Worlds: The Identity Politics of Eurasians in Masters' Bhowani Junction
}

\author{
Sheeba V. Rajan \\ Assistant Professor, Department of English, St. Xavier's College for Women, Aluva, Ernakulam, Kerala, India.
}

\begin{abstract}
This research paper is an attempt to understand the complexities the Eurasians face during the British Raj period. The identity crisis of the Eurasians-people of mixed descent- a blend of Anglos and Indiansis beautifully portrayed by John Masters in his novel Bhowani Junction. The novel is notable for its portrayal of the Anglo Indian community who are closely involved with the Indian railway system. By analyzing the crises in the life of the Eurasians, the novel resolves the dilemmas and gives the readers' a soothing effect.
\end{abstract}

Keywords - Anglo-Indian, British Raj, Dilemma, Domiciled European, Eurasian.

\section{INTRODUCTION}

Raj fiction or Anglo Indian fiction began with Rudyard Kipling and ended when India won independence in 1947. Though nestled within the corpus of Anglo Indian literature, Raj fiction's defining feature is that it is set in the present and in one way or another it reflects the British presence in India.

The fiction of the British Raj period manifests the features such as an indisputable cultural gulf between the two people, the British disapproval of intermarriage, a preference for the Muslims over the Hindus, the ridicule of the Bengali and the Western educated Indian, the dismissal of the nationalist as a person of no consequence and the ignoring of the Christian missionary and his work. The Eurasians that appear in the fiction of this period are stereotyped but there is an attempt to understand the complexity of their situation. The predicament of the Eurasians is that they found themselves devoid of a country and a home.

\section{John Masters' Bhowani Junction}

John Masters' Bhowani Junction, published in 1954, is a gripping tale of Anglo Indians who sway between cultural and historical cross currents. It is an in-depth study of the Eurasian psyche and it reveals the tensions in the minds of Eurasians, as to which country they belong. Masters dovetails romance and history in the back drop of the time of the transfer of power. He brings out with sympathy and understanding the hardships and the injustices to which they have been subjected in the society.

During the $18^{\text {th }}$ century, the Eurasian community enjoyed its days in the times of the lavish, earthy nabobs. The Anglo-Indian alliances were taken for granted and their offsprings were accepted as the part of a prosperous Empire. In 1858, when the British parliament took over administration of the country from John's company, the concubinage between the Anglos and the Indians was strongly resented. It became a fashion for the writers to present the Eurasian community with a negative tint. The Eurasians were supposed to have imbibed the worst traits of both the races-the stubbornness and pride of the English and the deviousness or crookedness of the Indians. They are the fatal dilution of both Indian and English blood and they proved themselves to be unequal in the Empire.

Bhowani Junction is set amidst the turbulence of the British withdrawal from India-the violent months leading to Indian Independence. The heroine of the novel, Victoria Jones, an Anglo-Indian girl whose search for her identity in the new India forms the basis of the novel. She searches for a space of her own through her liaisons with a fellow Anglo-Indian, an Indian (Sikh) and a British Officer. Masters brings out the dichotomy of the Anglo-Indian that they are not accepted by the British and at the same time they feel to be superior to a native. Patrick Taylor, the Anglo Indian railway man, says “we couldn't go Home. We couldn't become English because we were half Indian. We couldn't become Indian, because we were half English. We could only stay where we were and be what we were. The English would go any time now and leave us to the Wogs" (27-28). That is the real dilemma of the Eurasian community.

In the beginning of the novel when Patrick Taylor meets Victoria, he says that the trouble faced by his old school and the plight faced by the Anglo Indians is the same. "The trouble being that the Anglo Indians did not want to sink to the level of the Indians, and the Indians hated as for being superior to them and St. Thomas' was a kind of symbol of the whole thing, because it was only for Anglo Indians and Domiciled Europeans" (12). Victoria has been courted by Taylor, in whom she sees as an embodiment of "the worst trademarks of Anglo Indian people-inferiority feelings, resentment, perpetual readiness to be insulted" (81) and these are the things that she want to get rid of in herself. Victoria's exposure to the world from the boundaries of the railway 
colony has opened her eyes and becomes irritated with the attitudes and inhibitions of her community as a whole. Victoria finds it difficult to mingle with British Society after being subjected to rape by Graham Macaulay, a British officer. After this incident, she searches for her roots in India. She believes that when the British leaves India, the only way for Anglo Indians have to live in India and to adopt the Indian culture and beliefs. The British officers consider Anglo-Indian women to be sexual objects but they are not ready to tie nuptial knot with these ladies. Eurasians try to assimilate Indian culture, beliefs and practices as their mind has been trained to imbibe the British ideas, beliefs and culture.

The words of Sardarini, an Indian and mother of Ranjith Singh Kasel, is an eye opener not to Victoria alone but to the entire Anglo Indian community. Sardarini says : "we are going to make you realise that you are Indians-inferior Indians, possibly disloyal Indians, because you have spent a hundred years licking England's boots and kicking us with your own boots that you are so proud of wearing. ... why dont you see that you are an Indian, and act like one ? we are strong now. We will look after you" (143). Victoria explores an Indian identity for herself, wearing the sari and she looks in the mirror. "It was me, but this person in the mirror was more beautiful than me. She was a beautiful Indian girl in her own clothes"(144 ). Later Victoria accepts her identity neither as a British nor as an Indian but a true Anglo-Indian. The author tries to bring out peace and harmony in the minds of Anglo-Indians that an Anglo-Indian can be in this world without fear, inferiority and inhibitions.

\section{CONCLUSION}

In the end of the novel, the reunification of Patrick and Victoria put an end to Anglo-Indians dilemma and the search of Victoria for true love and identity has come to an end.The Anglo-Indians create a culture and identity of their own, distinctive in its blend of East and West. It is not a question of suppressing the Anglo in Anglo-Indian but a question of releasing the Indian and making something truly Anglo-Indian.

\section{Acknowledgements}

The author is grateful to The State Central Library \& University Library, Thiruvananthapuram, Kerala, India for providing books and journals to carry out this research work.

\section{References}

[1] Blunt, Alison. "Land of our Mothers : Home, Identity and Nationality for Anglo-Indians in British India, 1919-1947". History Workshop Journal. 54 (2002) : 49-72. Print.

[2] Cowasjee, Saros, ed. A Raj Collection. New Delhi : Oxford University Press, 2005. Print.

[3] Mannsaker, Frances M. "East and West: Anglo Indian Racial Attitudes as Reflected in Popular Fiction". Victorian Studies 24.1 (1980) : 33-51. Print.

[4] Masters, John. Bhowani Junction. New Delhi : Penguin Books, 2007. Print. 